\title{
Comparative Assessment of Hydrocarbon Generation Potential of Organic Matter from Shale Sediments along Isugwuato - Okigwe Axis, Anambra Basin, SE Nigeria
}

\author{
*1'UZOEGBU, MU; UGWUEZE, CU
}

\author{
Department of Geology, University of Port Harcourt, Port Harcourt, Nigeria. \\ *Corresponding Author Email: uche.uzoegbu@ uniport.edu.ng; Tel: +2348030715958
}

\begin{abstract}
The Cretaceous sediments in the Anambra Basin (SE Nigeria) consist of a cyclic succession of coals, carbonaceous shales, silty shales and siltstones interpreted as deltaic deposits. The objective of this study is to compare the hydrocarbon generation potential of organic matter from shale sediments along Isugwuato-Okigwe axis in the Anambra Basin, Nigeria. Data obtained indicates the presence of Type III kerogen with Tmax values are between 424 and $441^{\circ} \mathrm{C}$ indicating that the shales are thermally immature to marginally mature with respect to petroleum generation. Hydrogen Index (HI) values range from 14 to $388.9 \mathrm{mgHC} / \mathrm{gTOC}$ while $\mathrm{S}_{1}+\mathrm{S}_{2}$ yields values ranging from 0.2 to $1.0 \mathrm{mgHC} / \mathrm{g}$ rock, suggesting that the shale have gas generating potential. The TOC values ranges from 1.3 to $3.0 \%$, an indication of a good source rock of terrestrially derived organic matter. The high oxygen index (OI) (16.3 mgCO $\mathrm{mg}_{2}$-1TOC), TS (1.35) and TOC/TS (1.5) suggest deposition in a shallow marine environment. Based on the kerogen type, shales from the studied area will equally generate oil and gas if its organic matter attained sufficient thermal temperature.
\end{abstract}

DOI: https://dx.doi.org/10.4314/jasem.v25i3.8

Copyright: Copyright () 2021 Uzoegbu and Ugwueze. This is an open access article distributed under the Creative Commons Attribution License (CCL), which permits unrestricted use, distribution, and reproduction in any medium, provided the original work is properly cited.

Dates: Received: 12 December 2020; Revised: 26 January 2021; Accepted: 12 February 2021

Keywords: Shale, kerogen type, maturity, oil generation.

The Anambra Basin became the site of major deposition following the Santonian folding in southeastern Nigeria. Compressional uplift of the Lower Benue Trough succession (Albian to Coniacian) along a NE-SW axis was accompanied by tectonic inversion and downwarping of the Anambra platform. Petroleum source rocks are the primary component of the petroleum system concept (Tissot and Welte, 1984; Magoon and Dow, 1994). Source rocks constitute the precursors of petroleum which, under favorable conditions, may subsequently migrate to reservoirs and be sealed to form accumulation. Nexant (2003) estimated about 32 billion barrels of oil and about 170 trillion cubic feet of gas in Nigeria that derives solely from the onshore and offshore Niger Delta. Some the proven reserves asset (Obaje et al., 2004). The inland basins of Nigeria comprise the Anambra. The Anambra Basin is a larger intracontinental basin that forms an arm of the lower Benue Trough (Obaje et al., 2004) with its NE-SW trending towards the Niger Delta (Fig. 1). Petroleum exploration in the Anambra Basin was triggered by the occurrence of surface seeps and dates back to the early 1930s (Kulke, 1995). However, the petroleum potential of this area has been under exploration and exploitation due to the Santonian inversion and the predominance of terrestrial sediments, as well as discoveries in the prolific Niger Delta in the south (Ekweozor and Gormly, 1983). Consequently, exploration companies' have been drilled many wells especially in the northeast margin to increase the national reserves. However, most of these wells were reported as dry holes. Therefore, it is necessary to adequately evaluate petroleum system multidisciplinary using basin modeling, geophysical and geochemical techniques (e.g., Ratnayake et al., 2014; Ratnayake and Sampei, 2015b; Uzoegbu and Ikwuagwu, 2016a). In this study, the authors consider to estimate source rocks characteristics in this basin by using well established geochemical techniques such as total organic carbon (TOC), hydrogen index, Tmax and biomarker validation. The objectives of this study were to characterize a shale sample from the basin using modern techniques of petroleum geochemistry in order to: (i) assess in detail the quality of its organic matter; (ii) evaluate its thermal evolution, and (iii) highlight its potential as a source. The results of this study may stimulate further interest in petroleum exploration and exploitation in the Anambra Basin.

\section{MATERIALS AND METHODS}

Stratigraphic Setting: The Studied area Ihube, Lokpanukwu and Uturu lies within Anambra Basin in the Lower Benue Trough, (Reyment, 1965; Short and 
Stauble, 1967) and have the following lithostratigraphic divisions in Figure 2. Sedimentation was restricted to the Calabar area before the regression and thermo-tectonic event that occurred during the Santonian times. According to many workers, this thermo-tectonics is related to the initiation of the formation of the Afikpo Basin and Anambra Basin. All Pre-Santonian beds were folded, faulted and uplifted to form the Okigwe-Abakaliki Anticlinorium trending NE-SW. Murat (1972) Identified three major structural cycles in Southeastern Nigeria:

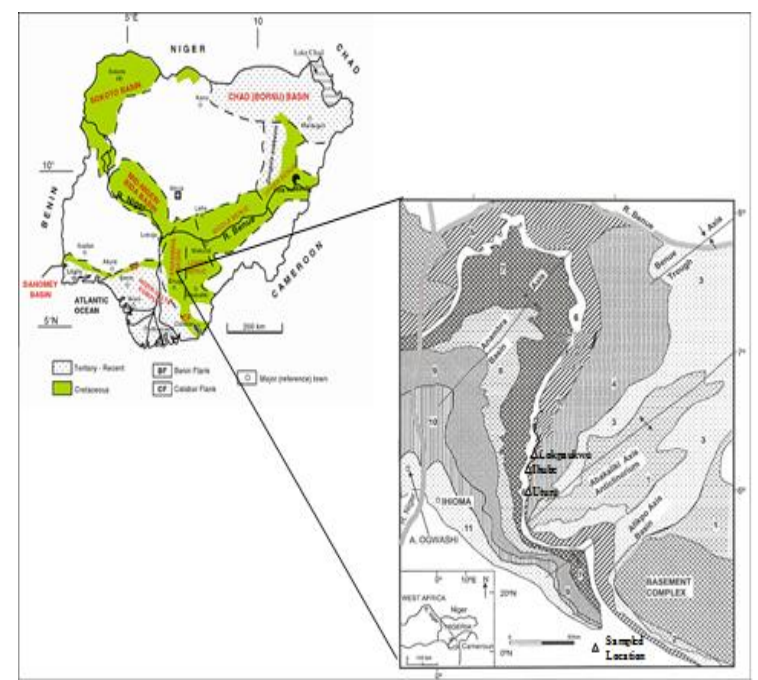

Fig. 1: Generalized geological map of Nigeria (boxed areas of inset) showing the geological map of the Anambra Basin. Numbers indicate Cretaceous and Tertiary formations shown as follows: $\mathbf{1}$.

Asu River Group; 2. Odikpani Formation; 3. Eze-Aku Shale; 4. Awgu Shale; 5. Enugu/Nkporo Shale; 6. Mamu Formation; 7. Ajali Sandstone; 8. Nsukka Formation; 9. Imo Shale; 10. Ameki

Formation and 11. Ogwashi-Asaba Formation (modified from Akande et al., 2007).

1. The Aptian-Early Santonian, related to the initial rifting of the southern Nigerian continental region and opening of the Benue Trough. This phase produced two principal sets of faults trending NE-SW and NWSE. The NE-SW set of faults bound the Benue Trough, while the

NW-SE deformed sedimentary beds within the Calabar Flank.

2. The Turonian-Santonian, was characterized by compressional movements resulting in the folding of the Abakaliki Anticlinorim and the development of the complementary Afikpo Syncline.

3. The Late Campanian-Middle Miocene phase, which produced rapid subsidence and uplift in alternation with subsequent progradation of a delta.

During the Coniacian, beds of rapid changing lithofacies including shale, limestone and an increasing amount of sandstone were deposited in South-Eastern Nigerian. The rapid facies change has been interpreted by Short and Stauble (1967). It followed by the first indication of onset of active tectonic phase of folding, faulting and upliftment which ended during Santonian. These Santonian movements resulted in the folding and upliftment of the NE striking Abakaliki Anticlinorium which in turn led to the exposure and subsequent erosion of the Coniacian, Turonian and Albian Formations. Consequent to this uplift, two depressions were formed flanking the Abakaliki Anticlinorium; the wide Anambra Basin to the NW and the narrow Afikpo Syncline to the South East (Kogbe, 1976). These two depressions became the main depositional basins from the Campanian to Palaeocene.

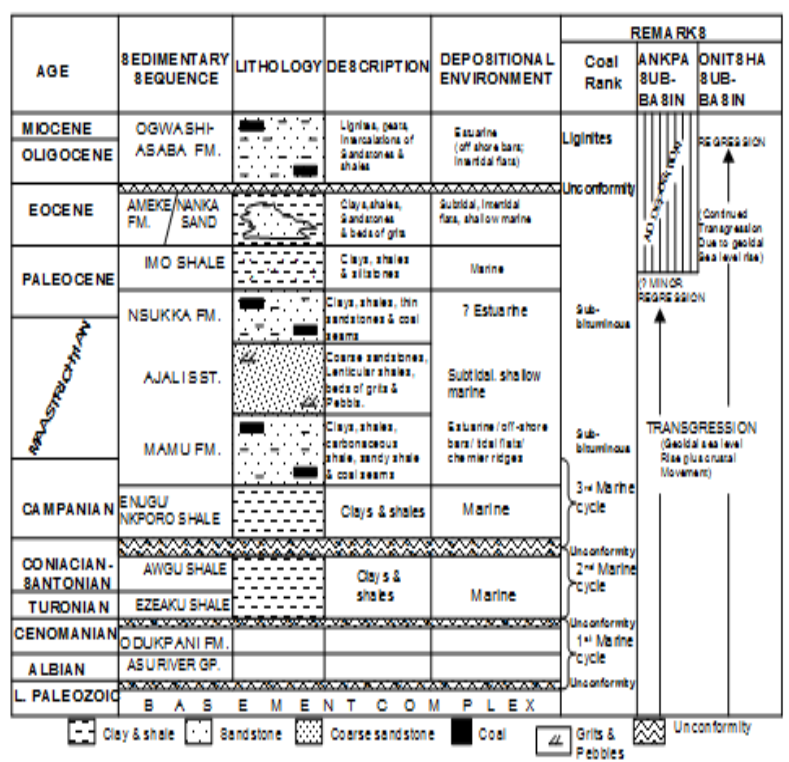

Fig. 2: The stratigraphy and environment of deposition of sediments in the Anambra Basin southeastern Nigeria (modified Uzoegbu et al., 2014).

Sample Collection and pretreatment: Two methods of sample collection were employed within this study. These are the grab and bulk sampling methods. Although the grab method of sampling is not the best for collection of samples for analysis, it was used here to get representative samples from Ihube (HUB), Lokpaukwu (LKP) and Uturu (UTU) for Nkporo Shale in order to carry out laboratory analyses on a large scale. Hammer, chisel, and sample bags were used for the collection of the samples.

The samples collected were labeled according to each locality. Care is taken to avoid sampling weathered coal sections or contamination in the samples. A total of 10 samples were collected from Ihube, Lokpaukwu and Uturu. The number of samples from any of this locality was based on the accessibility of the sample area and the extent to which the shale is developed at the outcrop (Plate 1: A, B and C). 

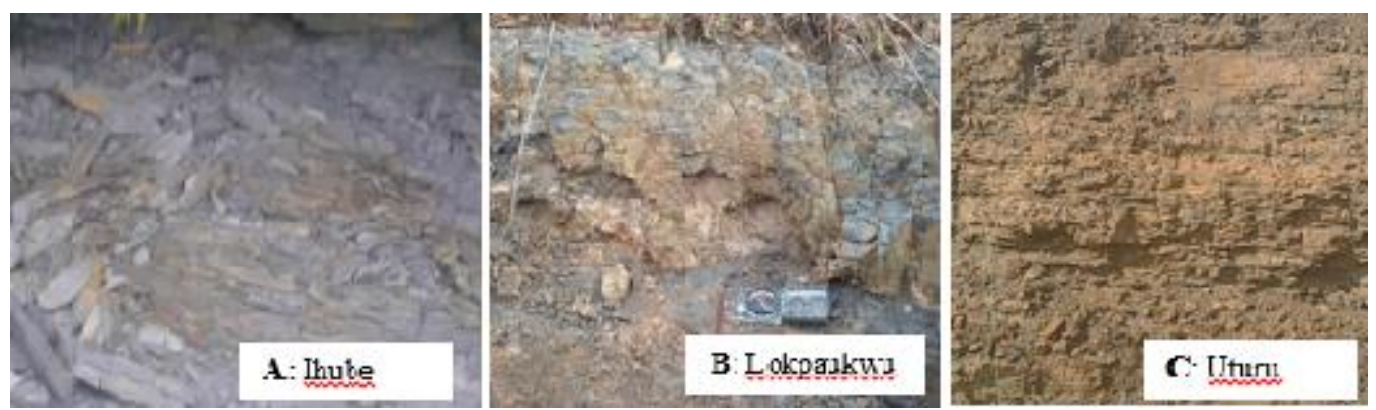

Plate 1: $\mathrm{A}=$ Ihube, $\mathrm{B}=$ Lokpaukwu and $\mathrm{C}=\mathrm{Uturu}$, showing the sampled pictures.

Samples Preparation: A total of ten bulk shale samples (about 30-50 g) were used for the analyses. The samples were washed using water/organic solvent to remove the dirty and sands on them. The washed samples were kept in the oven for 24 hours to dry at temperature of $40^{\circ} \mathrm{C}$. The dried samples were crushed by BB 200 Jaw crusher. After that, each of these crushed samples was divided into two equal parts. Half of the crushed samples in each case was packaged in a plastic bag and the remaining half was pulverized by vibratory disc mill Model RS 100 to $<50 \mu \mathrm{m}$ size. $11-$ $36 \mathrm{mg}$ of the pulverized samples were weighed in crucibles with a balance weighing instrument model Sartorius ISO 9001. The weighed samples together with the crucibles were placed in a Rock-Eval 6 machine for free oil content $\left(S_{1}\right)$, pyrolysable hydrocarbon content $(\mathrm{S} 2)$, amount of $\mathrm{CO}_{2}\left(\mathrm{~S}_{3}\right)$ and maximum temperature (Tmax). Another portion of the samples $(30$ - 40mg) were weighed in crucibles with a balanced instrument model Sartorius ISO 9001. The measured samples were subjected to Leco C-S analyser for total organic carbon (TOC) and total sulphur (TS).

\section{RESULTS AND DISCUSSION}

Organic matter richness: Table 1 describes the parameters use for interpretation of result in this study. Each location was sampled at various distance outcrops with the elevation above the mean sea-level noted using GPS. Carbon is an essential element of any organic compound, and one way to assess the organic richness of a rock is to measure its carbon content. The amount of organic carbon is usually measured as total organic carbon (TOC) (Jarvie, 1991; Ogala, 2011; Ratnayake and Sampei, 2015a). RockEval analysis was performed on 10 potential source rock samples (Table 1). Total organic carbon in a source rock comprises three basic components: (1) organic carbon in a retained hydrocarbons as received in the laboratory; (2) organic carbon that can be converted to hydrocarbons, called convertible carbon (Jarvie, 1991) or reactive or labile carbon (Cooles et al., 1986) and (3) a carbonaceous organic residue that will not yield hydrocarbons because of insufficient hydrogen commonly referred to as inert carbon (Cooles et al., 1986; Jarvie, 1991). Adequate amount of organic matter is a necessary prerequisite for sediment to generate oil or gas (Cornford, 1986, Uzoegbu and Ikwuagwu, 2016b).High TOC contents of $>1.95 \mathrm{wt} \%$ and hydrogen index (HI) between 14 and $388.9 \mathrm{mg} \mathrm{HC} / \mathrm{g}$ TOC characterise the shale beds of the study locality (Table 1). The shale have TOC contents of 1.3 to $3.0 \mathrm{wt}$.\% and HI values between 14 and $388.9 \mathrm{mg} \mathrm{HC} / \mathrm{g}$ TOC. Variation in HI between 14 and $388.9 \mathrm{mg} \mathrm{HC} / \mathrm{g}$ TOC on the shale samples, suggests Type III OM (Peters, 1986).

\begin{tabular}{|c|c|c|c|c|c|c|c|c|c|c|c|c|c|c|}
\hline $\begin{array}{l}\text {.Sampl } \\
\text { e } \\
\text { Name }\end{array}$ & $\begin{array}{l}S_{1} \\
\mathrm{mg} / \mathrm{g}\end{array}$ & $\begin{array}{l}\mathrm{S}_{2} \\
\mathrm{mg} / \mathrm{g}\end{array}$ & $\begin{array}{l}\mathrm{S}_{3} \\
\mathrm{mg} / \mathrm{g}\end{array}$ & $\begin{array}{l}S_{1}+S_{2} \\
\mathrm{mg} / g\end{array}$ & $\begin{array}{l}\text { Tmax } \\
\left({ }^{\circ} \mathrm{C}\right)\end{array}$ & $\begin{array}{l}\text { TOC } \\
(w t \%)\end{array}$ & PI & $\begin{array}{l}\mathbf{S}_{\mathbf{2}} \\
/ \mathbf{S}_{\mathbf{3}}\end{array}$ & $\begin{array}{l}\mathrm{S}_{1} / \\
\text { TOC }\end{array}$ & $\begin{array}{l}\text { HI } \\
\text { mgS }_{2} / \\
\text { gTOC }\end{array}$ & $\begin{array}{l}\mathrm{OI} \\
\mathrm{mgS}_{3} / \\
\text { gTOC }^{\prime}\end{array}$ & $\begin{array}{l}\text { HI/ } \\
\text { OI }\end{array}$ & TS & $\begin{array}{l}\text { TOC/ } \\
\text { TS }\end{array}$ \\
\hline HUBT1 & 0.0 & 0.2 & 0.6 & 0.2 & 441 & 1.3 & 1.2 & 0.32 & 0.01 & 137.4 & 42.75 & 3.21 & 1.04 & 1.26 \\
\hline HUBB2 & 0.0 & 0.8 & 0.2 & 0.8 & 424 & 2.0 & 1.8 & 3.50 & 0.01 & 388.9 & 11.11 & 35.00 & 1.59 & 1.25 \\
\hline LKPT2 & 0.0 & 0.7 & 0.4 & 0.7 & 426 & 2.1 & 1.7 & 1.82 & 0.00 & 343.0 & 18.84 & 18.21 & 2.19 & 0.95 \\
\hline LKPB1 & 0.0 & 0.7 & 1.2 & 0.7 & 426 & 3.0 & 1.7 & 0.59 & 0.00 & 248.3 & 41.84 & 5.93 & 1.35 & 2.18 \\
\hline UTU1 & 0.0 & 0.3 & 0.2 & 0.3 & 435 & 1.5 & 0.1 & 1.32 & 0.03 & 16.0 & 12.00 & 1.33 & 0.90 & 1.68 \\
\hline UTU2 & 0.1 & 0.9 & 0.2 & 1.0 & 438 & 3.0 & 0.1 & 4.43 & 0.02 & 31.0 & 7.00 & 4.43 & 1.10 & 2.68 \\
\hline UTU3 & 0.0 & 0.2 & 0.1 & 0.2 & 432 & 1.3 & 0.2 & 1.38 & 0.03 & 14.0 & 9.00 & 1.56 & 0.88 & 1.52 \\
\hline UTU4 & 0.0 & 0.1 & 0.1 & 0.3 & 426 & 1.4 & 0.1 & 2.78 & 0.03 & 18.0 & 6.00 & 3.00 & 1.23 & 1.12 \\
\hline UTU5 & 0.1 & 0.1 & 0.1 & 0.5 & 435 & 1.5 & 0.1 & 4.09 & 0.03 & 29.0 & 7.00 & 4.14 & 1.30 & 1.18 \\
\hline UTU6 & 0.1 & 0.2 & 0.2 & 0.8 & 439 & 2.4 & 0.1 & 4.0 & 0.03 & 30.0 & 7.00 & 4.29 & 1.93 & 1.24 \\
\hline
\end{tabular}

$N B$ : T1, T2, and B1 and B2 represent top and bottom samples.

These TOC values show that the sediments have comparable average TOC contents, which are greater than the 0.5 wt. \% threshold value required for a potential source rock to generate hydrocarbons (Tissot 
and Welte, 1984). The highest TOC value of $3.0 \mathrm{wt} \%$ was obtained from the bottom of second sample location number LKPB2 and third sample location UTU2. The organic matter content of the first sample location (HUBT1) from the top of the outcrop locality is quite low (1.3 wt\%) compared with that of the HUBB2 sample which has a moderate organic matter content of $2.0 \mathrm{wt} \%$. TOC of $3.0 \mathrm{wt} \%$ was obtained from the second location LKPT1. This made the second location (LKP) best in organic richness as compared to location UTU2. The source rock quality of the shales in the three locations (Fig. 3) is confirmed by the pyrolysis-derived generative potential (G.P. = $\mathrm{S}_{1}+\mathrm{S}_{2}$ ) of selected samples (Table 1). The hydrocarbon generative potential of Ihube, Lokpaukwu and Uturu ranges from 0.2 to $0.8 \mathrm{mg} / \mathrm{g}$ rock, $0.7 \mathrm{mg} / \mathrm{g}$ rock and 0.2 to $1.0 \mathrm{mg} / \mathrm{g}$ rock respectively. Hydrogen index (HI) values for the studied samples ranges from 137 to $388.9 \mathrm{mgHC} / \mathrm{g}$ TOC for Ihube, 248 to $343 \mathrm{mgHC} / \mathrm{g}$ TOC and 14 to $31 \mathrm{mgHC} / \mathrm{g}$ TOC for Lokpaukwu and Uturu respectively. These values indicate a moderately good source rock with oil and gas generating potential. Tissot and Welte (1984) and Peters and Cassa (1994) agreed that G.P. > $2 \mathrm{mg} / \mathrm{g}$ form an excellent source rock. The observed increase in PI and $S_{1} /$ TOC supports the hydrocarbon generative potential of these shale samples. The generative capacities of these shales are high and with prospect for hydrocarbons, despite the low PI ( 0.1 to 1.8$)$ for all the samples that is not close to the "oil window" of 1.0 (Tissot and Welte, 1984; Uzoegbu, 2018; Uzoegbu and Ikwuagwu, 2016a,b). The Hydrogen Index (HI) is proportional to the amount of hydrogen contained within the kerogen, and high HI indicates a greater potential to generate oil. Kerogen types can be inferred from these indices as well. The $\mathrm{HI}$ is derived from the ratio of hydrogen to TOC; i.e, $\mathrm{S}_{2} /$ TOC x 100 . Samples within the study area are having $\mathrm{HI}$ values within the range of 14 to $388.9 \mathrm{mg} \mathrm{HC} / \mathrm{g}$ TOC with an average value of $125.6 \mathrm{mg} \mathrm{HC} / \mathrm{g}$ TOC.

Types of organic matter: The type of organic matter in sediments from the three locations (Ihube, Lokpaukwu and Uturu) was assessed by Rock-Eval pyrolysis (Table 1). Most of the studied rock units from the three areas are mainly of type III with subordinate type IIIII. The $\mathrm{S}_{2}$ values correspond to the hydrocarbons that evolve from the sample during the second programmed heating stage of pyrolysis. These hydrocarbons result from the cracking of heavy hydrocarbons and from the thermal breakdown of kerogen. It represents the milligrams of residual hydrocarbons in one gram of rock, thus indicating the potential amount of hydrocarbons that the source rock might still produce if thermal maturation continues. Samples from the Ihube locality are having their $\mathrm{S}_{2}$ values within the range of 0.2 to $0.8 \mathrm{mg} / \mathrm{g}$ with an average of $0.5 \mathrm{mg} / \mathrm{g}$ while that of Lokpaukwu and Uturu ranges between 0.71 to $0.73 \mathrm{mg} / \mathrm{g}$ and 0.3 to 1.0 $\mathrm{mg} / \mathrm{g}$ with an average of 0.7 and $0.3 \mathrm{mg} / \mathrm{g}$ respectively. The $S_{2}$ vs. TOC diagrams gave an average $\mathrm{HI}$ value of 399mg HC/g TOC for shale samples (Fig. 3). Therefore, most of the Anambra Basin shale samples were dominated type III with associated type II. The gas-prone nature of these shales $\left(\mathrm{S}_{2} / \mathrm{S}_{3} ; 0.3-4.4\right)$ from the study area rules out type II kerogen, which usually shows $\mathrm{S}_{2} / \mathrm{S}_{3}$ greater than 5 (Eseme et al., 2006; Uzoegbu and Ikwuagwu, 2016b; Uzoegbu and Amoke, 2017) (Table 1). Plots of $\mathrm{S}_{2}$ vs. TOC and determining the regression equation of average $\mathrm{HI}$ of $399 \mathrm{mg} \mathrm{HC/g}$ TOC has been used by Langford and Blanc-Valleron (1990) as the best method for determining the true average $\mathrm{HI}$ and measuring the adsorption of hydrocarbons by the rock matrix. The plots Rock-Eval $S_{2}$ versus TOC (Fig. 3) are useful to compare the petroleum-generative potential of source rocks (Langford and Blanc-Valleron, 1990; Peters, 1986; Ogala, 2011). HI obtained from Rock-Eval pyrolysis of shaly source rocks, in most cases, may be less than the true average $\mathrm{HI}$ of the sample due to the hydrocarbons adsorptive capacity of the source rock matrix (Espitalie et al., 1985). Therefore, the regression equation derived from the $\mathrm{S}_{2}$ vs. TOC graph can be used to automatically correct HI for this effect.

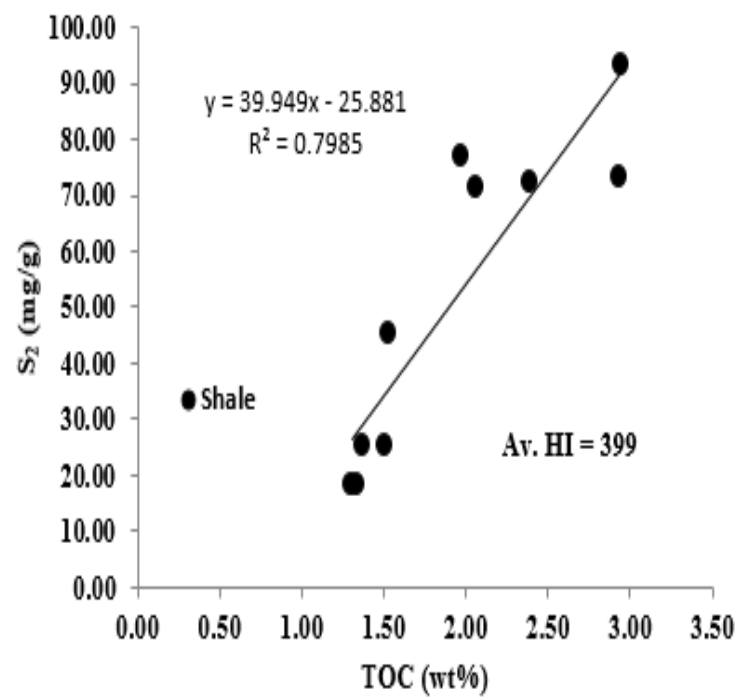

Fig. 3: A diagram of $S_{2}$ versus TOC of shale samples with calculated average hydrogen indices (Av. HI).

The average HI of the study shale samples from the $\mathrm{S}_{2}$ vs. TOC plots is very reliable (correlation coefficient is 0.80 ) which indicated a value of $399 \mathrm{mg} \mathrm{HC} / \mathrm{g}$ TOC (Fig. 3) which is above $300 \mathrm{mg} \mathrm{HC} / \mathrm{g}$ TOC (Peters, 1986) supporting the predominant of the type III with associated type II organic matter of the Anambra Basin. The van Krevelen diagrams for the shale 
samples show a dominance of type III (Figs. 4). The highest HI samples may be assigned to a highpotential type II kerogen at the diagenesis/ catagenesis boundary (Obaje et al., 2004; Uzoegbu, 2018). The slopes of lines radiating from the origin in Figure 4 are directly related to hydrogen index $\left(\mathrm{HI}=\mathrm{S}_{2} \times 100 / \mathrm{TOC}\right.$, $\mathrm{mg} \mathrm{HC/g}$ TOC). The relationship between the hydrogen indexes (HI) versus oxygen index (OI) (Fig. 4) reveals kerogen of type III organic matter which is predominantly gas prone.

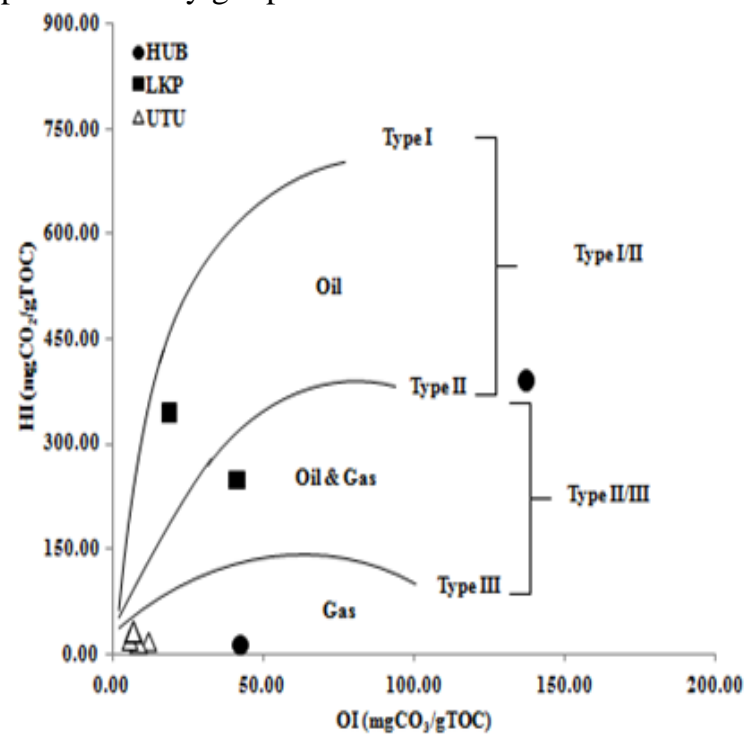

Fig. 4: Showing kerogen type from modified van Krevalen diagram (After Peters, 1986).

All the samples from Lokpaukwu indicated Type I/II while Ihube and Uturu samples shows Type II/III and Type III respectively. HI vs. Tmax diagram classifies the organic matter (OM) in the shale as type III kerogen (Akande et al., 2007). HI values for the Ihube, Lokpaukwu and Uturu samples range from 14 to $388.9 \mathrm{mgHC} / \mathrm{g}$ TOC and $\mathrm{S}_{1}+\mathrm{S}_{2}$ yields range from 0.2 to $1.0 \mathrm{mg} \mathrm{HC} / \mathrm{g}$ rock, suggesting that the shales have gas and oil-generating potential (Akande et al., 2007; Ogala, 2011; Uzoegbu and Amoke, 2017). Peters (1986) has suggested that at thermal maturity equivalent to vitrinite reflectance of $0.6 \%$ (Tmax $435^{\circ} \mathrm{C}$ ), rocks with $\mathrm{HI}$ above $300 \mathrm{mg} \mathrm{HC} / \mathrm{g}$ TOC produce oil; those with $\mathrm{HI}$ between 300 and 150 produce oil and gas; those with HI between 150 and 50 produce gas, and those with less than 50 are inert. The van Krevelen diagram is generated by plotting the Hydrogen Index (HI) against maximum temperature (Tmax) as shown in Fig. 5. The corresponding HITmax diagram based on the values given by Peters (1986) indicates some potential between oil and gas with gas dominating (Fig. 5 and 6). Plots of HI versus Tmax (the maximum temperature of pyrolysis) (Fig. 5) and Tmax versus HI (Fig. 6), also shows that the organic matter in the samples is mainly type III with oil, oil/gas and gas prone. The above results are in agreement with the data obtained by earlier workers (Akaegbobi and Schmitt, 1998; Akande et al., 2007; Ogala, 2011; Shanmugam, 1985; Uzoegbu and Ikwuagwu, 2016b)). Majority of the samples falls into fields that have hydrocarbon generative potential (Figs. 5 and 6).

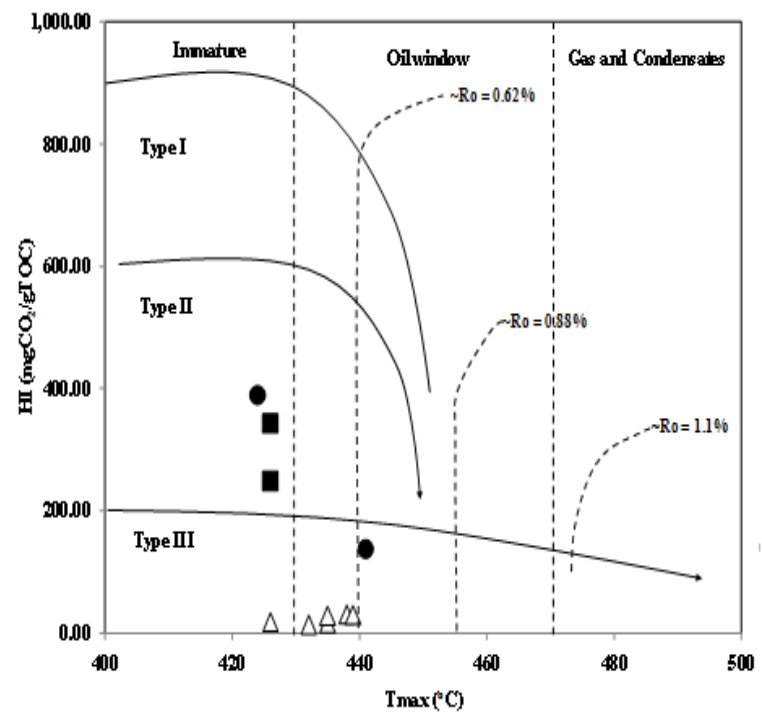

Fig. 5: A plot of HI versus Tmax indicating type of organic matter and maturity level.

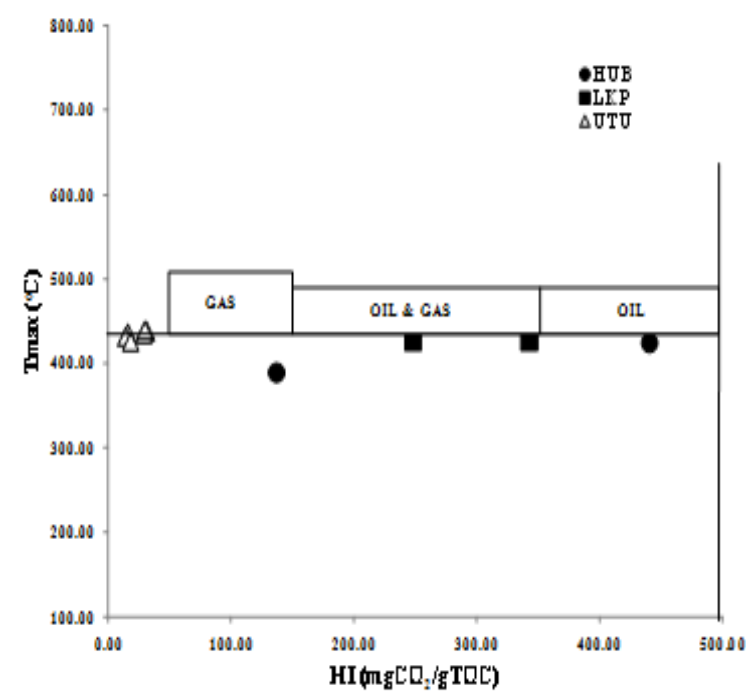

Fig. 6: A diagram of Tmax versus HI of shale samples from the study area describing the quality of organic matter.

A Plot of the SOM (extract yield) against TOC as proposed by Landis and Connan (1980) in Jovancicevic et al. (2002) for the shale samples indicates migration of oil has taken place in sample number HUBB2, LKPT2, LKPB1, UTU2, UTU5 and UTU6 respectively (Fig. 7). This diagram does not recognize the oil source rock potential of coals and 
coaly samples and can therefore not be used to evaluate such samples.

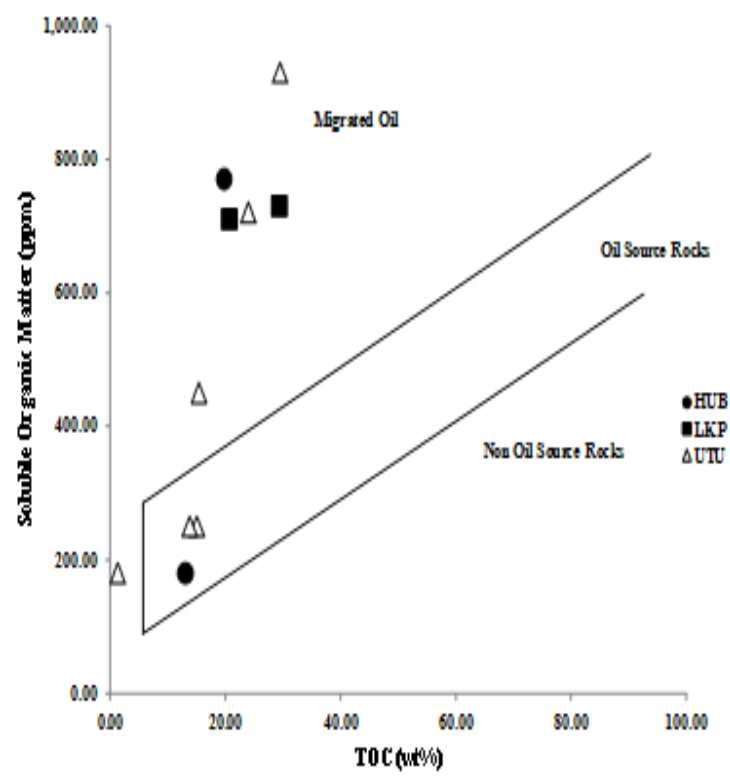

Fig. 7: A diagram showing the characterization of organic matter: SOM. vs TOC (based on Landais and Connan in Jovancicevic et $a l ., 2002$ ) of samples from Anambra Basin indicating migrated oil in the area.

This is supported by the diagram of $S_{1}+S_{2}$ vs TOC (Fig. 8) characterizing the shale samples from the study area as good source rocks with TOC and $\mathrm{S}_{1}+\mathrm{S}_{2}$ above $0.1 \mathrm{wt} \%$ and $0.55 \mathrm{mg} / \mathrm{g}$ respectively. This is also supported by the report of Beka et al. (2007) from their investigations on shaly facies of gas prone sequences in the Anambra Basin based on the values of TOC (1.3-3.0 wt\%) and soluble organic matter (SOM) (180930ppm) which are indicative of good to excellent source potential (Fig. 8). Udofia and Akaegbobi (2007) also investigated the Maastrichtian sediments around Enugu escarpment of the Anambra Basin which revealed the exceeding minimum threshold TOC value (0.65-1.82 wt \%) for shale samples. According to Baskin (1997) classification, source rock with (HI) between 100-200 mg HC/g TOC are product of the organic matter type III. Peters and Cassa (1994) classified samples with (HI) less than $50 \mathrm{mg} \mathrm{HC} / \mathrm{g}$ TOC as organic matter type IV. The relatively low hydrogen index (HI) values of the studied samples which range from $137.40 \mathrm{mg} \mathrm{HC} / \mathrm{g}$ TOC to $388.90 \mathrm{mg}$ $\mathrm{HC} / \mathrm{g}$ TOC (Table 1) suggest that the source rocks have potential for gas. The low (HI) values reported in this study is comparable with low trend of $\mathrm{HI}$ reported in the Campanian to Maastrichtian source rock facies (except Coal samples) in the Nigerian sedimentary basins (Obaje et al, 2004; Ehinola et al, 2005, Ogala, 2011, Uzoegbu, 2018; Uzoegbu and Ikwuagwu, 2016a,b; Uzoegbu and Amoke, 2017). The production index $\left(\mathrm{PI}=\mathrm{S}_{1} / \mathrm{S}_{1}+\mathrm{S}_{2}\right)$ values $>0.1$ (Table 1$)$ observed on few samples indicate possible impregnation by migrated bitumen or contamination by mud additives as seen in Figure 7 (Clementz, 1979; Durand and Oudin, 1979; Uzoegbu and Ikwuagwu, 2016b). Other samples with PI-values within 0.1 correspond to the expected results. The study samples are mixed with recycled terrestrial organic worked organic matter (OM) pointing to type III (Fig. 5). These recycled organic matter $(\mathrm{OM})$ might have been transported by fluvial processes (Bird et al., 1995; Obaje et al., 2004) as found in prodelta shales of a delta system.

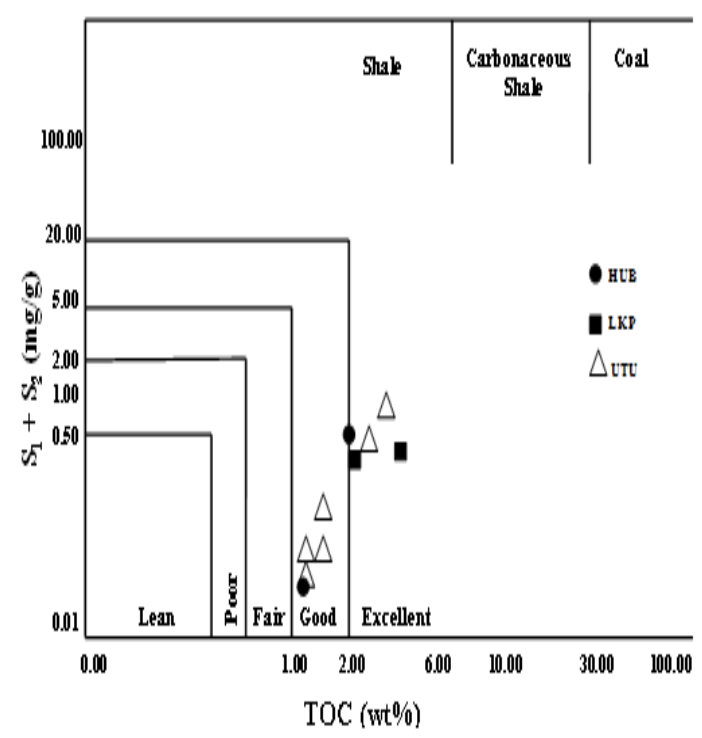

Fig, 8: A diagram indicating the quality of kerogen type in the shale samples: $S_{1}+S_{2}$ vs. TOC.

Thermal maturity of organic matter: Thermal maturity provides an indication of the maximum paleotemperature reached by a source rock. The Tmax values range from 424 to $441^{\circ} \mathrm{C}, 426^{\circ} \mathrm{C}$ and 426 to $439^{\circ} \mathrm{C}$ in Ihube, Lokpaukwu and Uturu respectively (Table 1$)$. In Ihube only sample HUBT $1\left(441^{\circ} \mathrm{C}\right)$ is mature and HUBB2 $\left(426^{\circ} \mathrm{C}\right)$ not mature. At Lokpaukwu (LKP) the whole of the samples are immature $\left(426^{\circ} \mathrm{C}\right)$. From Uturu only sample UTU4 with $426^{\circ} \mathrm{C}$ is immature while the rest of the samples UTU1, UTU2, UTU3, UTU5 and UTU6 with $435^{\circ} \mathrm{C}$, $438^{\circ} \mathrm{C}, 432^{\circ} \mathrm{C}, 435^{\circ} \mathrm{C}$ and $439^{\circ} \mathrm{C}$ respectively are at the marginally mature stage. The thermal maturity of the shales in the Anambra Basin has been discussed by several authors (Akaegbobi and Schmitt, 1998; Akaegbobi et al., 2000; Unomah and Ekweozor, 1993; Uzoegbu and Ikwuagwu, 2016a, b; Uzoegbu and Amoke, 2017). Wenger and Baker (1987) suggested that a PI from 0.07 to 1.77 is characteristic of source rocks in the oil window. The mean value of 0.7 for the shale samples is consistent with its Ro of 0.56 (Jovancicevic et al., 2002). This immaturity to 
maturity is also consistent with the lowering of fluorescing organic matter, as well as Rock-Eval Tmax of $426^{\circ} \mathrm{C}$, lower than the $430^{\circ} \mathrm{C}$ and $438^{\circ} \mathrm{C}$ above $435^{\circ} \mathrm{C}$ for high sulphur immature to mature source containing type III kerogen (Wenger and Baker, 1987; Landis and Connan, 1980 Uzoegbu and Ikwuagwu, 2016a,b; Uzoegbu and Amoke, 2017). Several authors have attempted to relate the thermostability (Tmax) of OM to carbon structures (Oberlin et al., 1980; Monthious et al., 1982; Landis et al., 1984), their terrestrial or marine origin (Walker et al., 1983; Leckie et al., 1988) and the initial hydrogen content as a function of reaction kinetics (Fang and Jianyu, 1992). This has led to the proposal that the thermostability of carbon structure increases with the increase in oxygen content due to cross linkages such that the oxygenated functions can form between stacks of adjacent molecules (Rouxhet et al., 1979; Furimsky et al., 1983). Walker et al. (1983) suggested marine derived amorphous-rich kerogens mature at lower temperatures than land plant (Type III) OM. Other investigators have demonstrated that terrestrial vitrinitic OM matures more rapidly than liptinic dominated organic matter (Tissot and Welte, 1984; Price and Barker, 1985; Wenger and Barker, 1987; Ikwuagwu and Uzoegbu, 2018) or that Tmax values for marine sediments increase more slowly with increasing maturation than for non-marine sediments (Leckie et al., 1988). Tmax vs Oxygen index are plotted (Fig. 9) as proposed by Landis et al. (1984) who concluded that the initial hydrogen contents of vitrinite macerals under different redox conditions are different and hence have different reaction kinetics, because there is a strong deviation from the normal trend expected of Type III OM on their OI vs. Tmax diagram. This led to their conclusion that the anomalies recorded are not a result of the thermal conditions. Applying these principles to the area of study, samples are plotted on the OI vs. Tmax diagram of Landis et al. (1984) to test if samples followed the typical trend for Type III OM, and hence to determine if the Tmax anomalies have any relationship to thermal conditions. The trends in the study shale samples show essentially a decrease in OI as Tmax increases indicating the maturity level (Fig. 9). This reflects the samples under study contain essentially Type III kerogen since they follow Landis et al. (1984) typical trend for Type III OM and immature to marginally mature stage. Also in agreement with the report of Fang and Jianyu (1992), thermal conditions are partially responsible for the suppression of Tmax in the samples. According to Fang and Jianyu (1992), if Ro variations are caused by thermal conditions, Tmax and Ro values would have to increase with decreasing OI values as obtained in this study. In the diagram Tmax vs. HI (Fig. 6) indicates that most of the
OM falls into oil and gas portion which implies that the OM contains oil and gas potential. Thermal maturity was confirmed by plotting the profiles of Tmax vs TOC (Fig. 10) showing that only HUBT1, UTU1, UTU2, UTU3, UTU5 and UTU6 shale samples from the study area attain to "oil window" $\left(430^{\circ} \mathrm{C}\right)$ while shale sample HUBB2, LKPT1, LKPB2 and UTU4 did not attain to threshold value and it is an immature. This is also supported by plotting the diagram of HI vs Tmax (Figs. 5 and 6) which determine the immaturity status of the entire samples from the study area.

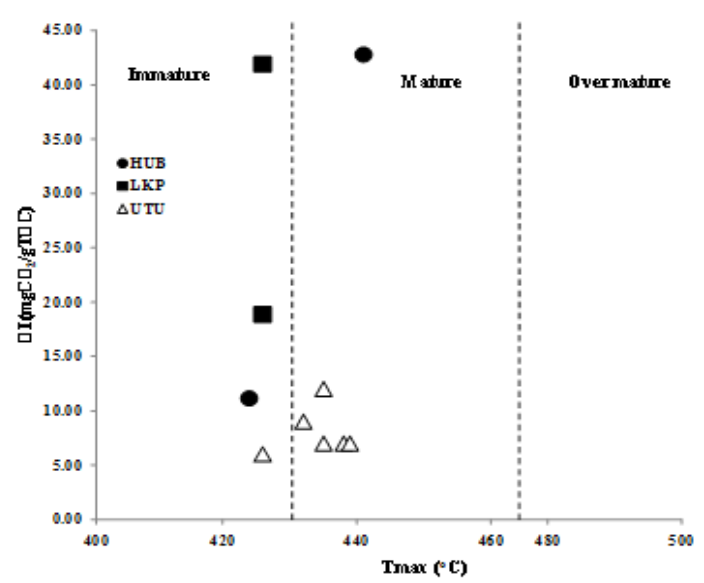

Fig. 9: A diagram of OI versus Tmax describing the anoxic and thermal of maturity organic matter in the shale samples within the

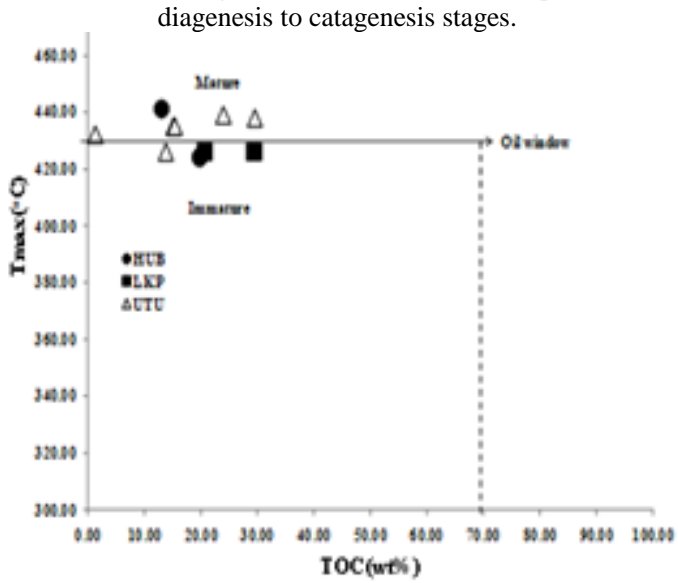

Fig. 10: To determine the maturity of the organic matter from shale samples using Tmax vs. TOC.

The hydrocarbon generative capacity $\left(\mathrm{S}_{1}+\mathrm{S}_{2}\right)$ shows that the study shale (0.2 to 1.0) HUBB2, LKPT2, LKPB1, UTU2, UTU5 and UTU6 have the highest residual potential to expel hydrocarbons as compared to the HUBT1, UTU1, UTU3 and UTU4 samples. The thermal maturation for the study shale is, however, still low. Although the $S_{1}+S_{2}$ of the locality involve are below but their thermal gas generation based on Tmax vs. HI and HI vs. OI indicates oil and gas potential. 
Depositional Environment: In well - oxygenated basins, such as the Anambra Basin organic matter is reworked and aerobically oxidised to such an extent that it becomes unstable for anaerobic microorganisms. In this case, sulphate reduction and subsequent methane generation are suppressed. The values of HI/OI range from 1.33 to 35.00 (Table 1) indicating the land derived organic matter. Samples with highly oxygenated OM are distinguishable by their very low $\mathrm{HI} / \mathrm{OI}$ ratio despite a terrestrial origin of the OM (Galimov, 2004; Uzoegbu, 2010). The majority of the terrestrial material is probably transported by fluvial processes (Bird et al., 1995; Obaje et al., 2004) contributing to the terrestrial source of OM of the study samples. The shale samples which is of kerogen type III with average OI of $16.30 \mathrm{mgS}_{3} / \mathrm{gTOC}$ and total sulphur (TS) of $1.35 \%$ describe depositional environment of the shale samples as shallow marine anoxic condition (Uzoegbu, 2010; Uzoegbu and Ikwuagwu, 2016b; Uzoegbu et al., 2013). The shale samples have elevated sulphur $(S)$ contents (Table 1$)$. The overall tendency towards lower sulphur $(\mathrm{S})$ with increasing TOC, as well as the TOC/TS ratios for shale $(0.88$ to $2.20 \%$; av. TOC/TS = 1.35) samples, argues for a marine environment during deposition as observed from the sulphur content (Berner, 1984; Ratnayake and Sampei, 2015a; Uzoegbu, 2010; Uzoegbu and Ikwuagwu, 2016b).

Conclusion: This study has shown that the coals and shales of the Maastrichtian Mamu Formation in the Anambra Basin, SE Nigeria has a total organic carbon (TOC) contents of up to $61.42 \mathrm{wt} \%$. The hydrogen index (HI) and generative potential (GP) of the shale samples in this study are above the minimum values required for a potential source rock, suggesting that the sediments have gas and oil generating potential. The organic matter is predominantly gas prone (mostly Type III and some mixed Type II/III). The level of thermal maturation derived from the Rock-Eval data show that the shale sediments are immature to marginally mature and partly within the oil window. The values of OI (16.3 $\left.\mathrm{mgCO}_{2} \mathrm{~g}-1 \mathrm{TOC}\right)$, TS (1.35) and TOC/TS (1.5) suggest deposition in a shallow marine environment.

\section{REFERENCES}

Akaegbobi, IM; Schmitt, M. (1998). Organic facies, hydrocarbon source potential and the reconstruction of depositional paleoenvironment of CampanoMaastrichtian Nkporo shale in the Cretaceous Anambra Basin, Nigeria. Nig. Assoc. Petrol. Expl. Bull., 13(1): 1-19.
Akaegbobi, IM; Nwachukwu, JI; Schmitt, M (2000). Aromatic hydrocarbon distribution and calculation of oil and gas volumes in post-Santonian shale and coal, Anambra Basin, Nigeria. In: Mello, M.R., and Katz, B.J., (eds.), Petroleum systems of south Atlantic margins. Ameri. Assoc. Petrol. Geol. Mem., (73): 233245 .

Akande, SO; Ogunmoyero, IB; Petersen, HI; Nytoft, HP (2007). Source rock evaluation of coals from the lower Maastrichtian Mamu Formation, SE Nigeria. $J$. Petrol. Geol., 30(4): 303-324.

Beka, F; Ukaegbu, V; Oluwajana, O; Oledinma, N; Njoku, I; Beka, J; Amaechi, L; Udoh, M (2007). "Spatial profiling of shaly facies and palaeoenvironment reconstruction of gas prone sequences in the Anambra Basin, Nigeria." Nig. Assoc. Petrol. Expl. 25 th Annual Conf., Abuja, Nig., 2007, p.25.

Berner, R A (1984). Sedimentary pyrite formation: an update. Geochem. Cosmochim. Acta, (48): 605-615.

Bird, MI; Summons, RE; Gagan, MK; Roksandic, Z; Dowling, L; Head, J; Fifield, LK; Cresswell, RG; Johnson, DP (1995). "Terrestrial vegetation change inferred from n-alkanes $13 \mathrm{C}$ analysis in the marine environment." Geochem. Cosmochim. Acta., (59): 2853-2857.

Clementz, DM (1979). Effect of oil and bitumen saturation on source-rock pyrolysis. Ameri. Assoc. Petrol. Geol. Bull., (63): 2227-2232.

Cooles, GP; Mackenzie, AS; Quigley, TM (1986). Calculation of petroleum masses generated and expelled from source rocks. In: Leythaeuser, D., and Rullkotter, J., (eds.), Advances in organic Geochemistry, Oxford, Pergamon. Org. Geochem., (10): 235-245.

Cornford, C (1986). Source rocks and hydrocarbons of the North Sea. In: Glennie, K.W., (ed.), Introduction to the Petroleum Geology of the North Sea, Oxford, U.K. pp. 197-236.

Durand, B; Oudin, JL (1979) Exemple de migration des hydrocarbons dans une serie deltaique:le delta de la Mahakam, Indonesie. Proc. 10th World Petrol. Congr. Bucharest, (2): 3-11.

Ehinola, O; Sonibare, OO; Falode, OA; Awofala, BO (2005). "Hydrocarbon Potential and Thermal Maturity of Nkporo Shale from Lower Benue Trough, Nigeria." J. Appl. Sci., (5): 689-695.

Ekweozor, CM; Gormly, JR (1983). Petroleum geochemistry of Late Cretaceous and Early Tertiary 
Shales penetrated by Akukwa-2 well in the Anambra Basin, Southern Nigeria. J. Petrol Geol., (6): 207 216.

Eseme, E; Littke, R; Agyingi, CM (2006). “Geochemical characterization of a Cretaceous black shale from Mamfe Basin, Cameroon." Petrol. Geosci., (12): 69 74, 2006.

Espitalie, J; Devoo, G; Marquis, F (1985). La pyrolyse Rock-Eval et ses applications (Deuxieme Partie). Rev. L'Ints. Franc. Du Petrole, 40(5): 563-784.

Fang, H; Jianyu, C (1992). "The cause and mechanism of vitrinite reflectance anomalies." J. Petrol. Geol., 15(4): 419-434.

Furimsky, E; Mc Phee, JA; Vancea, LA; Nandi, B (1983). "Effect of oxidation on the chemical nature and distribution of low-temperature pyrolysis products from bituminous coals." Fuels, pp. 395-400.

Galimov, EM (2004). The pattern of $\delta^{13} \mathrm{C}$ versus HI/OI relation in recent sediments as an indicator of geochemical regime in marine basins: comparison of the Black Sea, Kara Sea and Cariaco Trench. Chem. Geol., (204): 287-301.

Ikwuagwu, CS; Uzoegbu, MU (2018). Comparative Assessment of Hydrocarbon Potential of Cretaceous Coals from the Benue Trough, Nigeria. Int'al J. Res. Pubn., 5(2): http://ijrp.org/paper_detail/167, doi: 1005252018166

Jarvie, DM (1991). Total organic carbon (TOC) analysis. In: Merril, R.K., (ed.), Treatise of petroleum geology: Handbook of petroleum geology, source and migration processes and evaluation techniques. Ameri. Assoc. Petrol. Geol., pp. 113-118.

Jovancicevic, B; Wehner, H; Scheeder, G; Stojanovic, K; Sainovic, A; Cvetkovic, O; Ercegovac, M; Vitorovic, D (2002). "Search for source rocks of the crude oils of the Drmno deposition (southern part of the Pannonian Basin, Serbia)." J. Serbian Chem. Soc., (67): $553-566$.

Kogbe, CA (1976). The Upper Cretaceous Abeokuta Formation of South Western Nigeria. Nigerian Field No. 4.

Kulke, H (1995). "Nigeria," in Regional Petroleum Geology of the World. Part II: Africa, America, Australia and Antarctica. In Kulke, H (eds.) Berlin, Gebrüder Borntraeger. pp. 143-172.

Langford, FF; Blanc-Valleron, M-M (1990), Interpreting Rock-Eval pyrolysis data using graphs of pyrolizable hydrocarbons versus total organic carbon. Ameri. Assoc. Petrol. Geol. Bull., (74): 799-804.
Landis, P; Connan, J (1980). "Relation uranium-matière organique dans deux basins francais: Lodève (Herault) et Cérilly-Bourbon - L'Archambault (Allier)." Bull. des Centres de Recherches Expl. Prod., Elf Aquitaine, (4): 709-757.

Landis, P; Monthious, M; Meunier, JD (1984). "Importance of the oxidation/maturation pair in the evolution of humic coals." Org. Geochem., (7): 249260.

Leckie, DA; Kalkreuth, WD; Snowdon, LR (1988). "Source rock potential and thermal maturity of Lower Cretaceous strata: Monkman Pass Area, Brtish Columbia." Ameri. Assoc. Petrol. Geol. Bull., 72(7): 820-838.

Magoon, LB; Dow, WG (1994). "The petroleum system," in the petroleum system - From source to trap. In Magoon, LB; Dow, WG (eds.) Am. Assoc. Petrol. Geol. Mem. (60): 3-24.

Monthious, M; Oberlin, M; Oberlin, A; Bourrax, X; Boulet, R (1982). "Heavy petroleum products microtexture and ability to graphitize." Carbon, (20): 167-176.

Murat, RC (1972). Stratigraphy and paleogeography of the Cretaceous and Lower Tertiary in Southern Nigeria. In: Dessauvagie, TFJ; Whiteman, AJ (eds.), African Geology, University of Ibadan Press, pp. 251266.

Nexant, (2003). "National oil and gas policy: A draft report prepared for the Bureau of Public Enterprises (Nigeria) by Nexant, Griffin House, First Floor South, 161 Hammersmith Road, London." Ameri. Assoc. Petrol. Geol. Bull., 88(3): 326-327.

Obaje, NG; Wehner, H; Scheeder, G; Abubakar, MB and Jauro, A (2004) "Hydrocarbon prospectivity of Nigeria's inland basins: From the viewpoint of organic geochemistry and organic petrology." Ameri. Assoc. Petrol. Geol. Bull., 88(3): 325-353.

Oberlin, A; Boulmier, JL; Villey, M (1980). "Electron microscopic study of kerogen microtexture." In: Durand, B (ed.)-Kerogen-Insoluble Organic Matter from Sedimentary Rocks. Editions Technip, Paris, France, pp. 191-241.

Ogala, JE (2011). Hydrocarbon Potential of the Upper Cretaceous Coal and Shale Units in the Anambra Basin, Southeastern Nigeria. Petrol. Coal, 53(1): 3544. 
Peters, KE (1986). Guidelines for evaluating petroleum source rock using programmed pyrolysis, Ameri. Assoc. Petrol. Geol. Bull., 70(3): 318-329.

Peters, KE; Cassa, MR (1994). Applied source rock geochemistry. In: The Petroleum System- From Source to Trap. In Magoon, LB; Dow, WG (eds.) Ameri. Assoc. Petrol. Geol. Mem. (60): 93-117.

Price, LC; Barker, CE (1985). "Suppression of vitrinite reflectance in amorphous rich kerogen- A major unrecognized problem.” J. Petrol. Geol., 8(1): 59-84.

Ratnayake, AS; Sampei, Y; Kularathne, CW (2014). "Stratigraphic responses to major depositional events from the Late Cretaceous to Miocene in the Mannar Basin, Sri Lanka.” J. Geol. Soc. Sri Lanka, (16): 5-18.

Ratnayake, AS; Sampei, Y (2015a). "Characterization of organic matter and depositional environment of the Jurassic small sedimentary basins exposed in the northwest onshore area of Sri Lanka." Org. Geochem., (31): 15-28.

Ratnayake, AS; Sampei, Y (2015b). "Preliminary prediction of the geothermal activities in the frontier Mannar Basin, Sri Lanka.” J. Geol. Soc. Sri Lanka, (17): 19-29.

Reyment, RA (1965). Aspects of geology of Nigeria. University of Ibadan press. pp. 145.

Rouxhet, PG; Villey, M; Oberlin, A (1979). "Infra-red studt of the pyrolysis products of sporopollenin and lignite." Geochim. Cosmochim Acta, (43): 17051713.

Shanmugam, G (1985). Significance of corniferous rain forests and related organic matter in generating commercial quantities of oil, Gippsland Basin, Australia. Ameri. Assoc. Petrol. Geol. Bull., (69): 1241-1254.

Short, KC; Stauble, AJ (1967). "Outline of Geology of Niger Delta.” Ameri. Assoc. Petrol. Geol. Bull., (51): 761-779.

Tissot, BP; Welte, DH (1984). Petroleum Formation and occurrence. $2^{\text {nd }}$ ed., Berlin, Springer Verlag, pp. 699.

Udofia, GG; Akaegbobi, IM (2007). "Integrated geochemical and organic petrographic characterization of the Campano-Maastrichtian sediments around Enugu Escarpment, Anambra Basin, Southeastern Nigeria." Nig. Assoc. Petrol. Expl. 25 th Annual Conf., Abuja, Nig., 2007, pp. 22.

Unomah, GI; Ekweozor, CM (1993). Petroleum sourcerock assessment of the Campanian Nkporo shale lower Benue Trough, Nigeria. Nig. Assoc. Petrol. Expl. Bull., 8(02): 172-186.

Uzoegbu, MU (2010). Technological properties and hydrocarbon generative potential of late Cretaceous coal deposits in the Anambra Basin, Nigeria. Ph.D Thesis, ATBU, Bauchi, pp. 75-84.

Uzoegbu, MU (2018). Geochemical Evaluation and Depositional Environment of the Campanian Sediments in the Dahomey Basin, Southwestern Nigeria. Int'al J. Res. Pubn., 3(1): http://ijrp.org/paper_detail/60, doi: 100315201859

Uzoegbu, M.U. and Ikwuagwu, C.S. (2016a). Hydrocarbon Generative Potential of Campanian Source Rock from Ihube, Anambra Basin, Nigeria. Inter. J. Geol. Min. 2(1), 053-063.

Uzoegbu, MU; Ikwuagwu, CS (2016b). Characterization of Organic Matter and Hydrocarbon Potential of Shale from Uturu, Isigwuato, SE Nigeria. Int'al J. Sci. Res. Pubn, 6(9): 754 - 759.

Uzoegbu, M.U. and Amoke, A.I. (2017). Oil Generative Potential of Shale from Asu River Group in the Afikpo Basin, Southeast Nigeria. International Journal of Geology and Mining, 3(1), pp. 081 - 089.

Uzoegbu, MU; Uchebo, UA; Okafor, I (2013). "Petroleum generation potential of late Cretaceous coals from the Anambra Basin, SE Nigeria." Nig. J. Manpower Dev. Change, 1(1): 102-120.

Uzoegbu, MU; Uchebo, UA; Ekeleme, IA (2014). "Relations between carbon isotope composition and other geochemical properties on hydrocarbon depositional environment." Nig. J. Strat. Res. Dev., 1(3): 14-36.

Walker, A; McCulloh, T; Peterson, N; Stewart, R (1983). "Discrepancies between anomalously low reflectance of vitrinite and other maturation indicators from Upper Miocene oil source rocks, Los Angeles Basin, California." Abst. Ameri. Assoc. Petrol. Geol. Bull., (67): p.565.

Wenger, LM; Baker, DR (1987). "Variation in vitrinite reflectance with organic facies examples from Pennylvanian. Cycltherms of the mid-continent, U. S. A." Org. Geochem., (11): 411-416. 